\title{
Experimental study of drying of green chili by solar air flat plate collector used obstacles
}

\author{
K. Aoues*, M. Zellouf*, A. Labed**, N. Moummi** \\ *Laboratoire de Génie Energétique et Matériaux, LGEM, Université de Biskra B.P. 145 R.P. 07000, Biskra, Algéria, \\ E-mail:aoues_kamel@yahoo.fr/aoueskamel@univ-biskra.dz \\ **Laboratoire de Génie Mécanique, LGM, Université de Biskra B.P. 145 R.P. 07000, Biskra, Algeria
}

cross ${ }^{\text {ref }}$ http://dx.doi.org/10.5755/j01.mech.23.3.14209

\section{Introduction}

The exploitation of solar energy requires the conversion, utilization and recovery of energy invariably involves a heat exchange process, which makes it imperative to improve the thermal performance of heat exchangers. Several viable engineering solutions, particularly with the use of heat transfer enhancement techniques, are available to achieve this objective. Constantinos, A. [1] classified the enhancement techniques as fluid, surface and compound enhancement techniques.

Performance of a solar air heater is adversely affected on account of low thermal capacity of air and absorber to air convective heat transfer coefficient, which needs design considerations, and to the extent possible, compensation.

For this purpose surface technique, which directly involve the heat-exchanger surface, are employed in solar air heaters that comes in contact with air. These techniques improve the thermal performance either by increasing the heat-transfer area with the use of corrugated/finned absorber surfaces or by enhancing the absorber to air convective heat transfer coefficient with the use of roughened surfaces in mobile vein.

Varun, et al. [2] carried out a review of roughness geometry in solar air heaters. They discussed different roughness geometries used in solar air heaters and explained the concept of artificial roughness, effects of various roughness parameters on the flow pattern and also briefly discussed the roughness geometries used in heat exchangers other than solar air heaters. Abdullah, A. H. et al. [3] determined thermal performance of flat plate solar collector using various arrangements of compound honeycomb. Mittal, MK. et al. [4] compared the effective efficiency of solar air heater shaving six different types of roughness elements on the absorber plate and reported that solar air heaters roughened with inclined ribs and wire mesh perform better in the upper and lower range of parameters considered respectively. Vishavjeet, H. et al. [5] review roughness element geometries used in solar air heaters for performance enhancement and 23 roughness geometries have been considered and technical information so obtained has been used to determine the best performing roughness element geometry from thermo-hydraulic point of view. Another form of roughness was experimented by Aoues, K. et al. [6-8] where are different forms. Labed, A. et al. [9] investigate in the performance of single- and double-pass solar air heaters through the use of various fin geometries.

In the drying solar application, we used the heat energy conversion by solar air flat plate collectors. Labed, A. et al. [10] investigated in the experimental studies of various designs of solar flat plate collectors in the application for the drying of green chili. Solar air flat plate collectors used of obstacles for application for the drying of grape are studied by Abene, A. et al. [11]. Ahmed-Zaid, A. et al. [12] have optimized the performance of the drying unit of the agricultural products by using of the obstacles in the collector duct. Karsli, S. [13] analysis a performance of four types of air heating flat plate solar collectors: a finned collector with an angle of $75^{\circ}$, a finned collector with an angle of $70^{\circ}$, a collector with tubes, and a base collector for drying applications.

This paper presents two parts of experimental studies. The first one is an efficiency evaluation of solar air heater supplied with obstacles and those of the collector without obstacles. In the second, we exploited the better configuration in the drying of green chili.

\section{Experimental setup and measuring}

The experimental system is composed of basically the air flat plate solar collector $(\mathrm{SAH})$ and its schematic view is shown in Fig. 1.

In this work, five solar air flat plate collectors were designed and constructed for comparison of their thermal performances. The main features of the five tested solar air collectors are described below. In this study, experiments were performed on the Mohamed khider University campus under the meteorological conditions in Biskra, Algeria $\left(34^{\circ} 48^{\prime} \mathrm{N}\right.$ latitude; $5^{\circ} 44^{\prime} \mathrm{E}$ longitude). All the collectors were placed facing south and with a slope angle of $34.8^{\circ}$ with respect to the horizontal line.

The system is comprised of flat plate solar collectors, an air circulation fan, air valves, a multimeter and a pyranometer, and some auxiliary and measurement devices. The fabrication materials for each of the collectors are the same. The each collector had $0.89 \mathrm{~m}$ wide, $1.95 \mathrm{~m}$ long, with a collection area of solar radiation of $1.73 \mathrm{~m}^{2}$. All the collectors had a $25 \mathrm{~mm}$ flow duct height, leading to a flow passage area of $0.02225 \mathrm{~m}^{2}$. The absorbing surface in all collectors was made of galvanized metal, $0.4 \mathrm{~mm}$ thick, painted with dull black paint. A simple glass sheet of $5 \mathrm{~mm}$ thickness is used as a cover with an air gap of about $25 \mathrm{~mm}$ thickness left between the absorber plate and the glass cover, for all collectors. For reduce heat losses, the bottom and sides of the collector are lagged by thermal insulation of $40 \mathrm{~mm}$ thickness by polystyrene. The whole test facility was supported by the frame, which rested on four wheels to provide the system rotational and anangular 

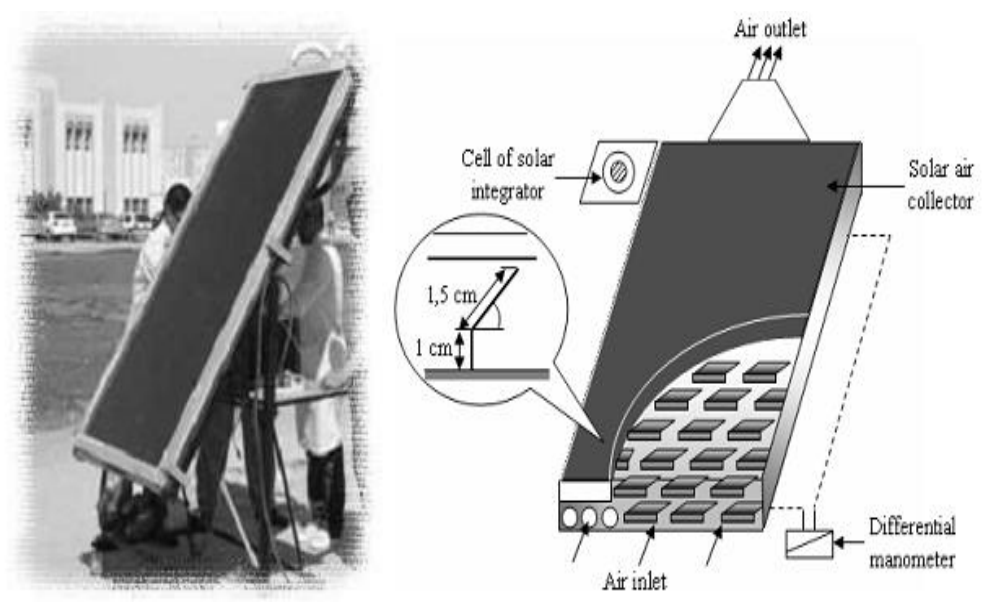

Fig. 1 Real and schematic view of experimental setup (Aoues, K. et al. [7])

alignment facility. The collector frame had also the facility of changing the angle of inclination of the collector.

To extract the maximum amount of heat from the absorber, one of the appropriate solutions is to introduce obstacles in the air stream. The objective of using these obstacles is to increase the output temperature of the collector, therefore the efficiency with minimum load losses.

The choice of the geometrical shapes of the obstacles to be used has to satisfy some criterion as the form and the disposition of the obstacles affects the air flow during its trajectory. The obstacles ensure a good air flow over the absorber plate, create the turbulence and reduce the dead zones in the collector.

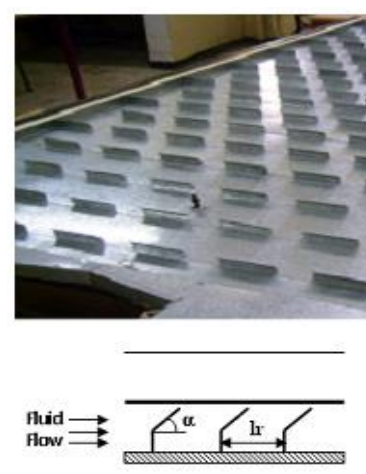

a

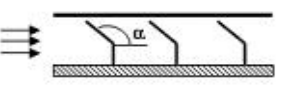

b
Fig. 2 Real and schematic view of obstacles: a - Model 1 with $\alpha=60^{\circ}$; b - Model 2 with $\alpha=120^{\circ}$

To have a clear idea about the gain provided by this solution, the first SAH is built without obstacles to compare his performance with their other collectors. The four other collectors were constructed with the obstacles placed in the dynamic air vein. These obstacles have taken two different forms and two different distances between successive rows. Fig. 2 shows the forms of obstacles utilized in this study. These obstacles formed with two parts; the first part is perpendicular and the second part is inclined, they are mounted in a staggered pattern, are oriented perpendicular to the fluid flow and are soldered to the back plate.

Case of SAH with different obstacles was mentioned as the following:

Case 1: there are no obstacles under the absorber (Fig. 3, a);

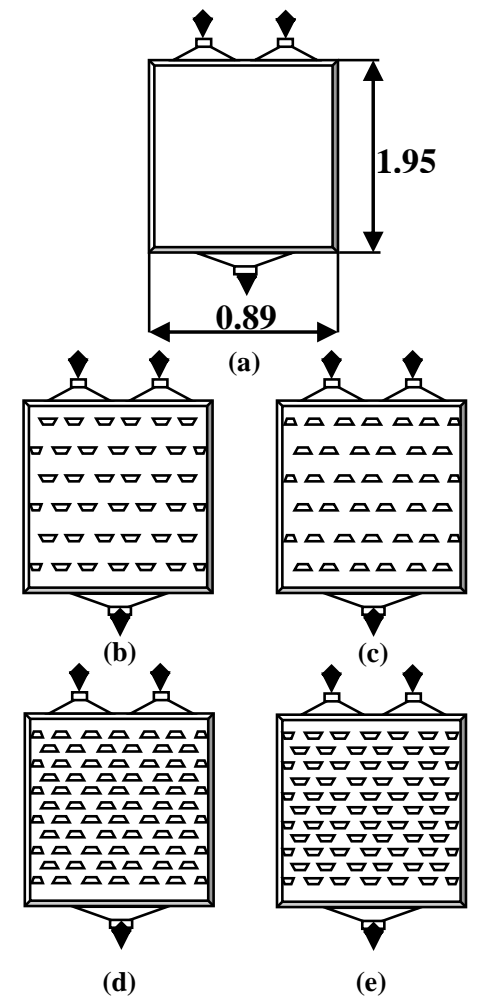

Fig. 3 Schematic views of air gap under absorber plate equipped with different obstacles: a - case 1 (without obstacles); b-case 2 ; c-case 3 ; d-case 4 ; e - case 5

Case 2: equipped with first form of obstacles and distance between successive rows, respectively, $\alpha=60^{\circ}$ and $d=100 \mathrm{~mm}$ (Fig. 3, b);

Case 3: have the second form of obstacles and distance between successive rows, respectively, $\alpha=120^{\circ}$ and $d=100 \mathrm{~mm}$ (Fig. 3, c);

Case 4: have taken the second form of obstacles and distance between successive rows, respectively, $\alpha=120^{\circ}$ and $d=50 \mathrm{~mm}$ (Fig. 3, d);

Case 5: equipped with first form of obstacles and distance between successive rows, respectively, $\alpha=60^{\circ}$ and $d=50 \mathrm{~mm}$ (Fig. 3, e).

\section{Experimental analysis}

The data for each test period are averaged. Know- 
ing the inlet and outlet fluid temperatures and the mass flow rate of air, the useful energy can be evaluated using Eq. (1). The useful energy may also be expressed in terms of the energy gained by the absorber and the energy lost from the absorber as given by Eq. (2):

$$
\begin{aligned}
& Q_{u}=\dot{m} c p\left(T_{f, \text { out }}-T_{f, \text { in }}\right) ; \\
& Q_{u}=\left(\tau_{v} \alpha_{a b s}\right) A_{c} I_{G}-U_{L} A_{c}\left(T_{a b s}-T_{a m b}\right) .
\end{aligned}
$$

The instantaneous collector efficiency relates the useful energy to the total radiation incident on the collector surface by Eqs. (3) or (4):

$$
\begin{aligned}
& \eta=\frac{Q_{u}}{A_{c} I_{G}}=\frac{\dot{m} c p\left(T_{f, \text { out }}-T_{f, \text { in }}\right)}{A_{c} I_{G}} ; \\
& \eta=\left(\tau_{v} \alpha_{a b s}\right)-\frac{U_{L}\left(T_{a b s}-T_{a m b}\right)}{I_{G}} .
\end{aligned}
$$

The collector efficiency can also be related to the inlet fluid temperature using Eq. (5):

$$
\eta=F_{R}\left[\left(\tau_{v} \alpha_{a b s}\right)-\frac{U_{L}\left(T_{f, i n}-T_{a m b}\right)}{I_{G}}\right] .
$$

The heat removal factor, FR, and the collector efficiency factor, F', are defined by Eqs. (6) and (7), respectively, according to Duffie, J. and Beckman, W. [14]:

$$
F_{R}=\frac{\dot{m} C p}{A_{c} U_{L}}\left[1-e\left(\frac{-F^{\prime} A_{c} U_{L}}{\dot{m} C p}\right)\right] .
$$

Another important parameter used to explain collector performance is collector efficiency factor $\left(F^{\prime}\right)$ calculated by Duffie, J. and Beckman, W. [14]:

$$
F^{\prime} U_{L}=-\frac{\dot{m} C p}{A_{c}} \ln \left(1-\frac{F_{R} U_{L} A_{c}}{\dot{m} C p}\right) .
$$

Since the measurements of inlet fluid temperature are more accurate than those of the plate temperature, it was decided to present the data using Eq. (5).

\section{Results and discussions}

The experiments were carried out under climatic conditions of Biskra city in Algeria. The collector slope was adjusted to $34.8^{\circ}$, which is considered suitable for the geographical location of Biskra $\left(34^{\circ} 48^{\prime} \mathrm{N}, 5^{\circ} 44^{\prime} \mathrm{E}\right)$. The collector was instrumented with k-type thermocouples for measuring temperatures of flowing air at the inlet and outlet of the collector, and the ambient temperature.

The experimental results include the performance of the solar collector without obstacles and the compound collectors with two different inclinations $\left(60^{\circ}\right.$ and $\left.120^{\circ}\right)$ and two different numbers of rows (19 and 37 rows) of obstacles units. They are five tested cases of the solar collector.

\subsection{SAHs efficiency improvement}

The collector efficiency improvements for simple pass type SAHs were calculated using Eq. (5). Various air mass flow rates between 0.018 and $0.043 \mathrm{~kg} / \mathrm{s}$ are also investigated in the experiments. Experimental studies had been performed during the spring period.

Figs. 4 and 5 shows the hourly variations of different temperatures (air inlet, outlet and ambient) of five cases of solar collector and two mass flow rates are 0.018 and $0.043 \mathrm{~kg} / \mathrm{s}$, during the experiments. The hourly measured solar radiation is also shown in Figs. 4 and 5. In Fig. 4 shown, the highest daily solar radiation is obtained as 905 , $798,828,684$ and $674 \mathrm{~W} / \mathrm{m}^{2}$ respectively for day tested the five cases. As expected, it increases in the morning to a peak value of $905,798,828,684$ and $674 \mathrm{~W} / \mathrm{m}^{2}$ for case 1 , case 2 , case 3 , case 4 and case 5 , respectively, at noon and starts to decrease in the afternoon. The hourly mean solar radiation is obtained as $812.35,535.55,705.2,552.8$ and $647.55 \mathrm{~W} / \mathrm{m}^{2}$ for case 1 , case 2 , case 3 , case 4 and case 5 , respectively.

During the experiments, the hourly variation of temperatures of five cases of solar collector at $0.043 \mathrm{~kg} / \mathrm{s}$ mass flow rate is shown in Fig. 5. The hourly measured solar radiation is also shown in Fig. 5. In Fig. 4 shown, the highest daily solar radiation is obtained as 910, 837, 850, 767 and $739 \mathrm{~W} / \mathrm{m}^{2}$ for case 1 , case 2 , case 3 , case 4 and case 5 , respectively. The hourly mean solar radiation is obtained respectively, at 849.78, 772.85, 753.90, 712 and $366.55 \mathrm{~W} / \mathrm{m}^{2}$ for case 1 , case 2 , case 3 , case 4 and case 5 , respectively.

The other parameters as a difference between the air inlet and outlet temperatures exhibit parallel changes with the instantaneous radiation. They depend directly on the amount of direct solar radiation for two air flow rates. Information on the temperature rise of air with solar radiation is important when designing SAHs. The temperature varies almost with solar radiation. The variation of air inlet and outlet temperature with incident radiation for all cases of solar collectors, presented in Figs. 6 and 7, is in an agreement with this observation. These plots of temperature difference versus insolation may be helpful to estimate the fluid temperature for any time of the day with the help of available meteorological data. The highest temperature increase occurred at the period of 11:30-14:00.

The maximum difference temperature increase through the five cases (1-5) SAHs compared with incident radiation was $27^{\circ} \mathrm{C}$ and $901 \mathrm{~W} / \mathrm{m}^{2}, 39^{\circ} \mathrm{C}$ and $775 \mathrm{~W} / \mathrm{m}^{2}$, $33^{\circ} \mathrm{C}$ and $821 \mathrm{~W} / \mathrm{m}^{2}, 23^{\circ} \mathrm{C}$ and $684 \mathrm{~W} / \mathrm{m}^{2}$ and $29^{\circ} \mathrm{C}$ and $667 \mathrm{~W} / \mathrm{m}^{2}$ for $0.018 \mathrm{~kg} / \mathrm{s}, 18.5^{\circ} \mathrm{C}$ and $910 \mathrm{~W} / \mathrm{m}^{2}, 32^{\circ} \mathrm{C}$ and $831 \mathrm{~W} / \mathrm{m}^{2}, 25^{\circ} \mathrm{C}$ and $843 \mathrm{~W} / \mathrm{m}^{2}, 18^{\circ} \mathrm{C}$ and $764 \mathrm{~W} / \mathrm{m}^{2}$ and $31^{\circ} \mathrm{C}$ and $739 \mathrm{~W} / \mathrm{m}^{2}$ for $0.043 \mathrm{~kg} / \mathrm{s}$ respectively. The highest difference temperature increase occurred through case 5, while the lowest through case 1. Figs. 6 and 7 shows that the intention of having the main heating of the air to occur when passing the collectors has been fulfilled. Figs. 4 and 5 also presents almost the same pattern in the temperature increase across the five cases of collectors.

In Figs. 8 and 9, we presents the collector efficiency versus the temperature parameter $\left(T_{f, i n}-T_{a m b}\right) / I_{G}$ for the four cases (2-5) SAHs with obstacles compared with the case $1 \mathrm{SAH}$ without obstacles at a mass flow rate of 0.018 and $0.043 \mathrm{~kg} / \mathrm{s}$, respectively. 

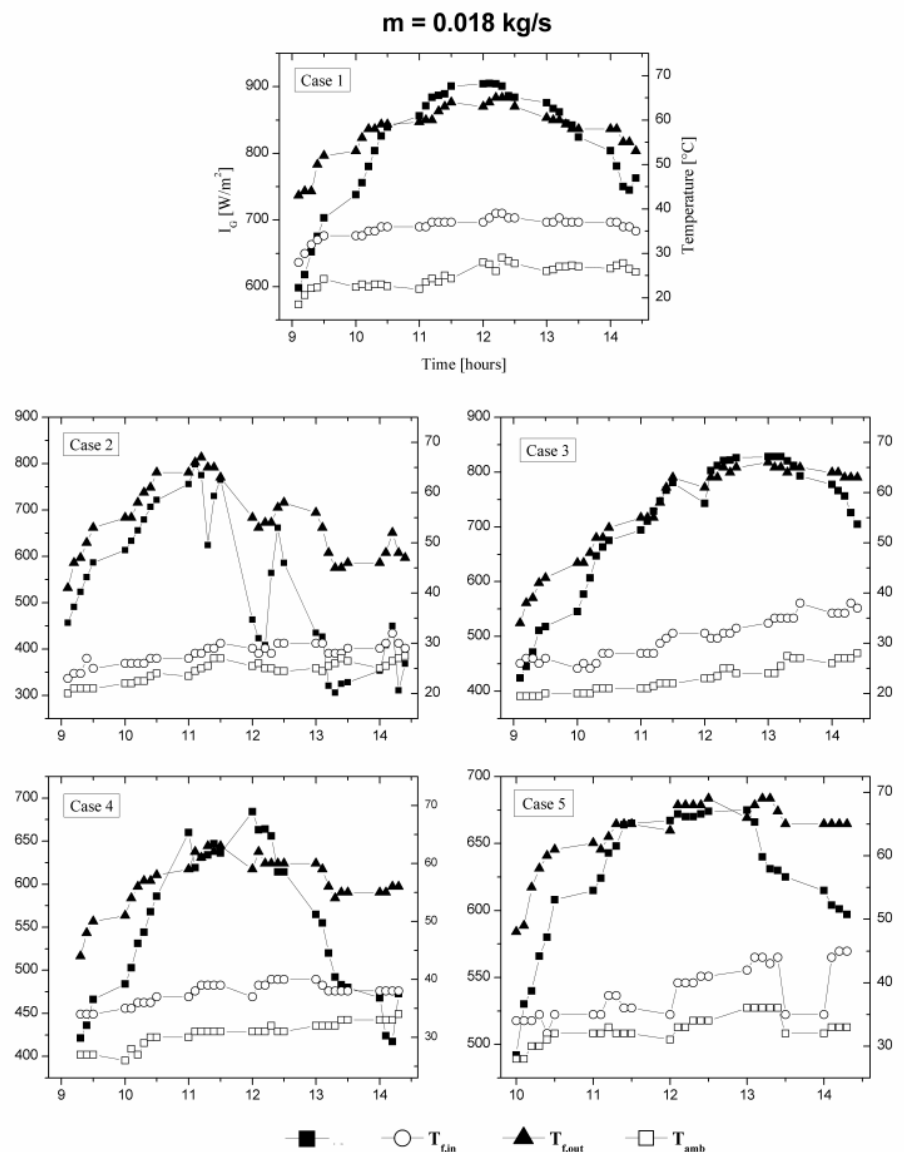

Fig. 4 Temperature variation of five cases (1-5) collector, average values of hourly solar radiation and ambient temperatures with time
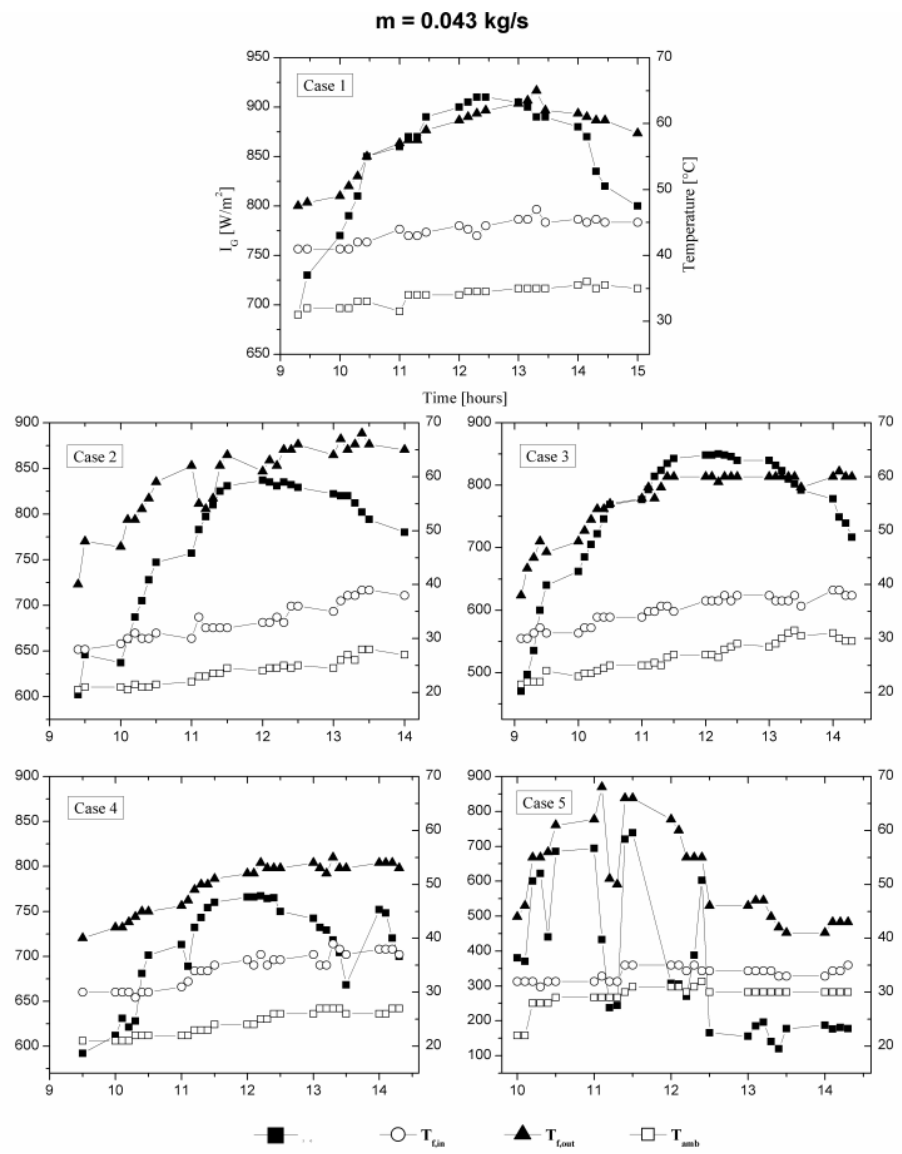

Fig. 5 Temperature variation of five cases (1-5) collector, average values of hourly solar radiation and ambient temperatures with time 


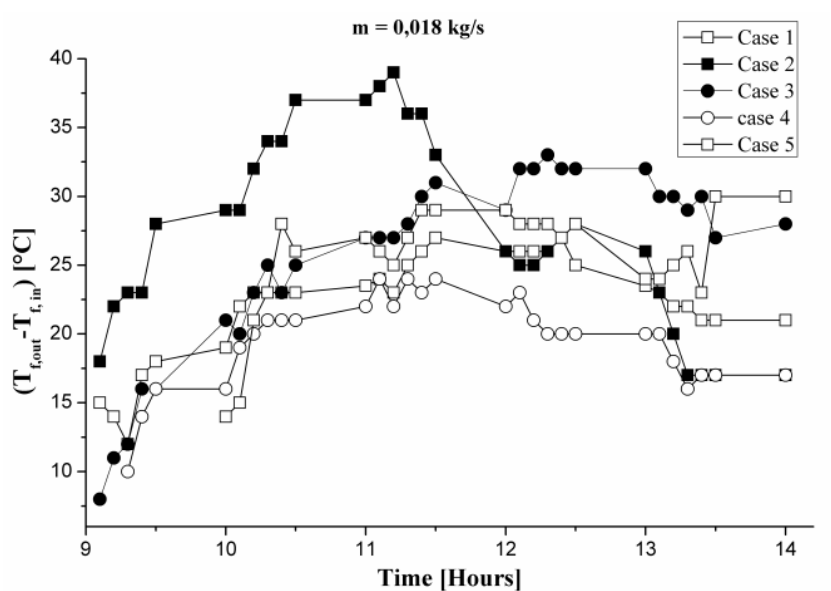

Fig. 6 Variation of instantaneous solar radiation and temperature difference with time

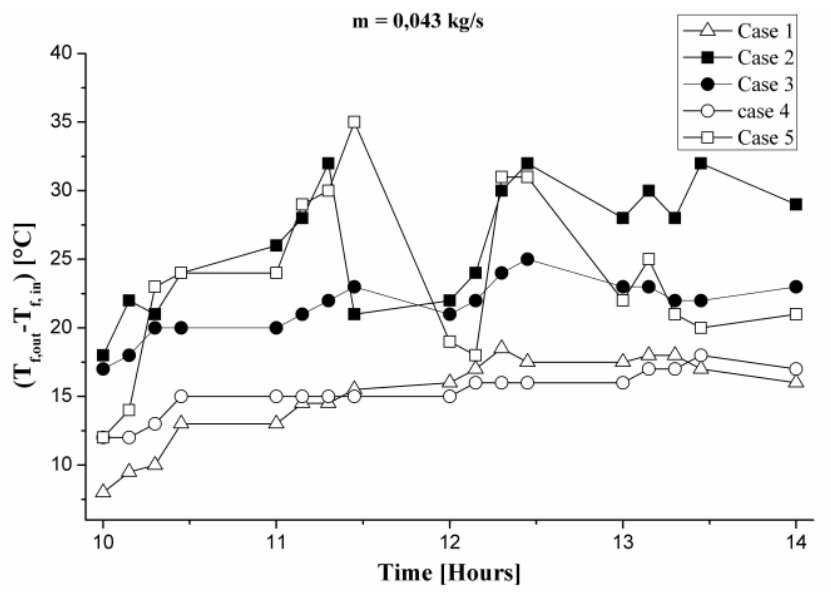

Fig. 7 Variation of instantaneous solar radiation and temperature difference with time

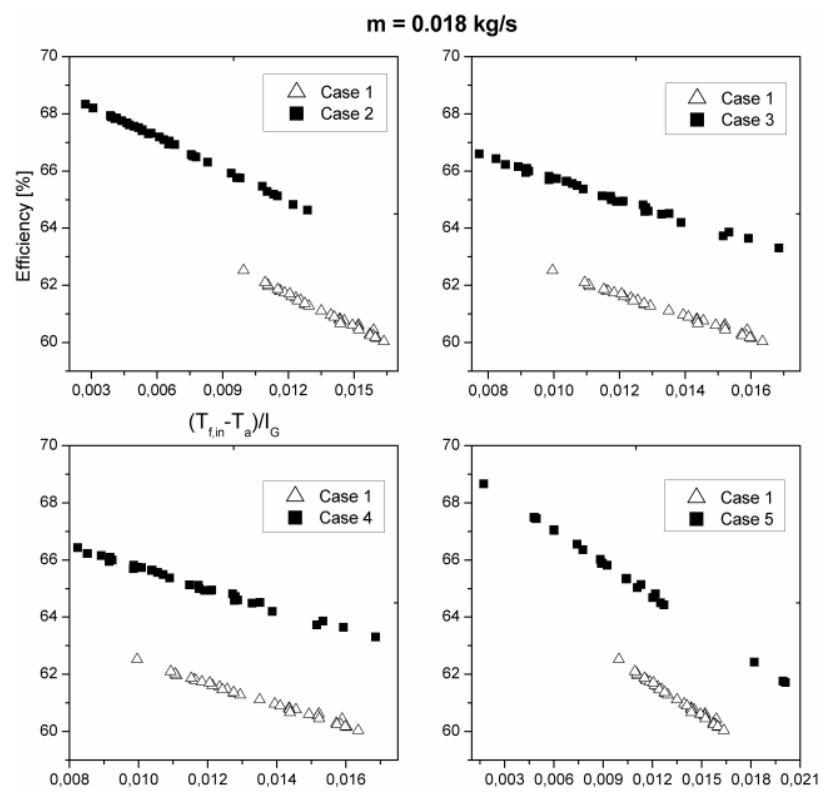

Fig. 8 Comparison between the thermal efficiency of the four cases (2-5) and case 1 (without obstacles)

The maximum efficiencies for case 1 , case 2 , case 3 , case 4 and case 5 are determined as $65 \%, 68.33 \%$, $66.6 \%, 66.07$ and $68.65 \%$ at $\dot{m}=0.018 \mathrm{~kg} / \mathrm{s}$, and $69.33 \%$, $70.16 \%, 69.82 \%, 69.32 \%$ and $72.09 \%$ at $0.043 \mathrm{~kg} / \mathrm{s}$. From the figure, it can be seen that, the efficiency of case 5 is higher than that of case 2, than that of case 3 and case 4 and also that of case 1 (without obstacles), respectively.
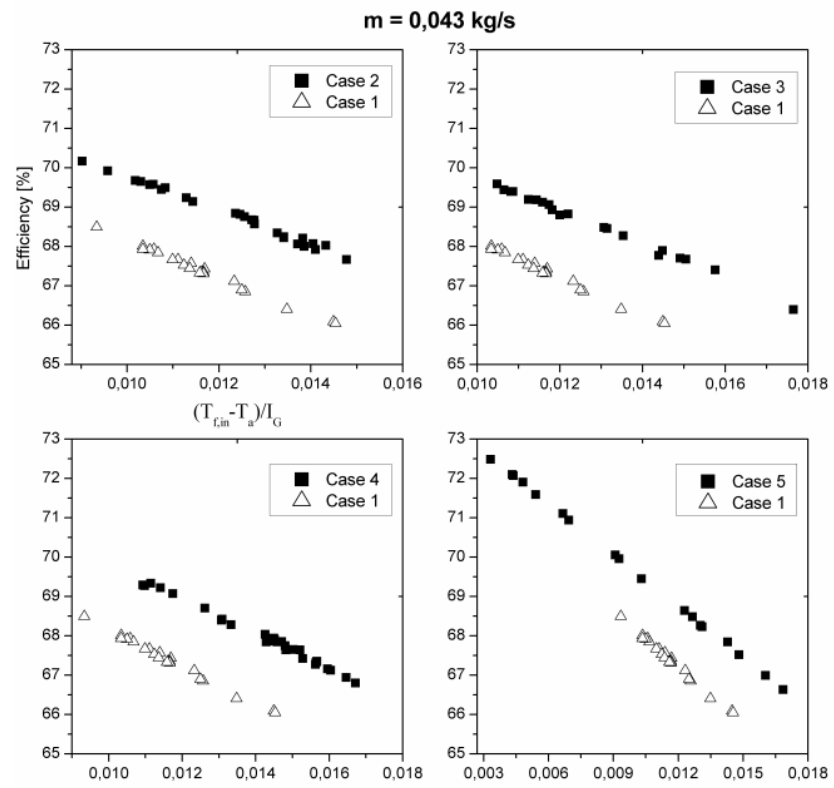

Fig. 9 Comparison between the thermal efficiency of the four cases (2-5) and case 1 (without obstacles)

To make a comparison of the thermal performance of the case 5, five configurations of SAHs reported in the literature were selected. Fig. 10 depicts the thermal

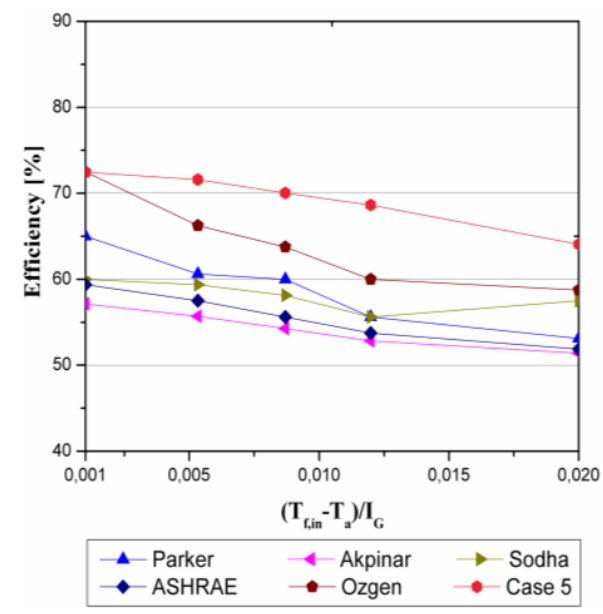

Fig. 10 Comparison between the thermal efficiency of the case 5 and the reported ones

efficiencies of the following authors: Parker, B. F. et al. [15] performed the thermal efficiency of an SAH of single air flow, double air flow collector for air mass flow rate of $0.0238 \mathrm{~kg} / \mathrm{s}$; Sodha, M. S. and Chandra, R.[16] used the two collectors designs of single air pass and double air pass, single glass cover with an optimal air mass flow rate from 0.02 to $0.08 \mathrm{~kg} / \mathrm{s}$; ASHRAE STANDARD [17] depicts in its standard, the thermal efficiency of a SAH using selective black chrome copper absorber single glass cover for air flow rate from 0.01 up to $0.03 \mathrm{~m}^{3} /\left(\mathrm{sm}^{2}\right)$. Ozgen, $\mathrm{F}$. et al. [18] performed the thermal efficiency of a SAH of double air having aluminium cans for two air mass flow rate of 0.03 and $0.05 \mathrm{~kg} / \mathrm{s}$. Akpinar, E. K. and Koçyigit, F. [19] designed a new single pass of flat plate solar air heater (SAH) with several obstacles. In the end, the higher effi- 
ciency shown in this figure corresponds to the designs proposed by this present study of single pass air flow case 5 SAHs, used a new design of obstacles, for an air mass flow rate of $0.043 \mathrm{~kg} / \mathrm{s}$.

\subsection{Improvement in drying time}

The drying technique has been made the object of many scientific communications and still remains a preferred research domain, particularly in countries where the traditional drying methods are still used. Since solar energy is free in comparison with other energy supplies such as electrical resistance heaters used in Konde, G. [20]. We have selected two systems with forced convection (Case 1 and Case 5) for comparison. These two systems are composed of an enclosure with one rack, a solar air flat plate collector with put obstacles (Case 1) and a fan. The drying chamber is a hard plastic drum of $8 \mathrm{~mm}$ thickness, $50 \mathrm{~cm}$ in diameter and $80 \mathrm{~cm}$ height, positioned meadows of the collectors and supported by a metal frame.

Fig. 11 shows a typical experimental evolution of moisture content of green chili and drying rate as a function of the drying time, in the case 1 and case 5 with $\dot{m}=0.0250 \mathrm{~kg} / \mathrm{s}$. Drying was started at 09:00 with an initial moisture content of $7.17 \mathrm{kgwater} / \mathrm{kg}(\mathrm{db})$ and continued until 16:00 (7 hours of drying time). The final moisture content of the samples obtained from case 1 is of $0.15 \mathrm{~kg}$ water $/ \mathrm{kg}(\mathrm{db})$, while it is about $0.00 \mathrm{kgwater} / \mathrm{kg}(\mathrm{db})$ after 6 hours of drying with case 5 .

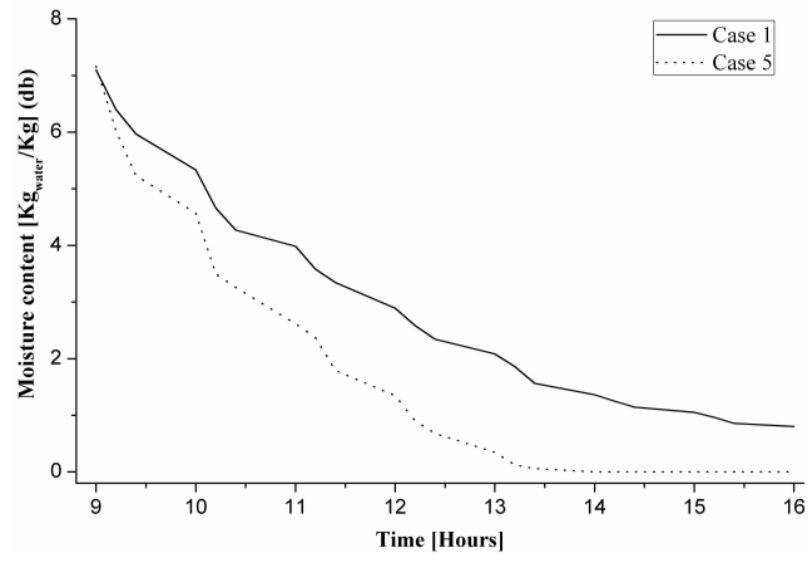

Fig. 11 Evolution of green chili Moisture content as a function of the drying time for different SAHs cases

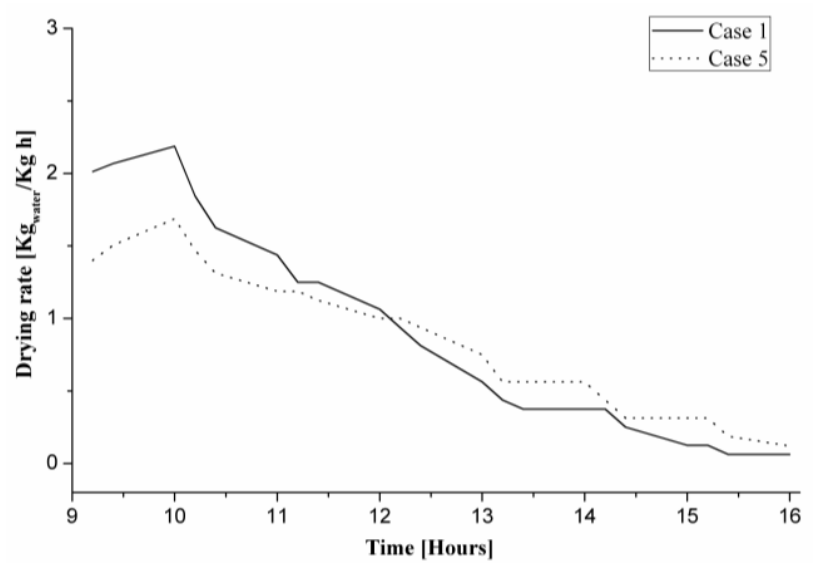

Fig. 12 Evolution of green chili drying rate as a function of the drying time for different SAHs cases
There is a relationship between drying rate and moisture content of the product during drying. As a result, the drying rate of green chili with Case 5 dryer was found to be higher than those of Case 1 in the first hours of drying (09:00-12:00), and it was lower in the last hours of drying time (09:20-16:00). This is due to the fact that the sample in Case 5 dryer loses the majority of its wet mass in the first hours of drying time and the moisture content of the sample in Case 1 dryers, what influences directly the rate transfer of moisture to the ambient air (Fig. 12).

\section{Conclusions}

In the first, the present study tested and compared the performances of five solar air heaters. Secondly, SAHs were tested in the drying application of the green chili. The following conclusions can be derived:

The efficiency of the solar air collectors depends significantly on the solar radiation, surface geometry of the collectors and extension of the air flow line. The efficiency of the collector improves with increasing mass flow rates due to an enhanced heat-transfer to the air flow. The efficiency increases as the temperature parameter increases, meaning, at higher temperature parameter, the overall loss is lower.

The highest collector efficiency and air temperature rise were achieved by SAHs with new form of obstacle (case 5), whereas the lowest values were obtained for the SAH without obstacles (case 1), Flat plate collector. In addition, this study has allowed us to show that the use of obstacles in the air flow duct of the collector is an efficient method of adapting in air exchanger according to user needs. Test results always yield higher efficiency values for case 5 than for case 1 (without obstacles) flat plate collector. The obstacles ensure a good air flow under the absorber plates, create the turbulence, and reduce the dead zones in the collector.

The study has shown that the solar collector case 5 leads to a very significant improvement in the efficiency/temperature rise couple, and in the reduction in drying time of the product.

\section{References}

1. Constantinos, A. 1990. A review of augmentation techniques for heat transfers surfaces in single-phase heat exchangers, Energy 15: 899-906.

http://www.sciencedirect.com/science/article/pii/03605 44290900719.

2. Varun; Saini, R.P.; Singal, S. 2007. A review on roughness geometry used in solar air heaters, Solar Energy 81: 1340-1350. http://dx.doi.org/10.1016/j.solener.2007.01.017.

3. Abdullah, A.H.; Abou-Ziyan, H.Z.; Ghoneim, A.A. 2003.Thermal performance of flat plate solar collector using various arrangements of compound honeycomb, Energy Conversion and Management. 44: 3093-3112. http://dx.doi.org/10.1016/S0196-8904(03)00013-X.

4. Mittal, M.K.; Varun; Saini R.P.; Singal, S. 2007. Effective efficiency of solar air heaters having different types of roughness elements on absorber plate, Energy 32(5): 739-745.

http://dx.doi.org/10.1016/j.energy.2006.05.009.

5. Vishavjeet, H.; Saini, R.P.; Saini, J.S.2009. Perfor- 
mance of artificially roughened solar air heaters -A review, Renewable and Sustainable Energy Reviews 13: 1854-1869.

http://dx.doi.org/10.1016/j.rser.2009.01.030.

6. Aoues, K.; Moummi, N.; Moummi, A.; Zellouf, M.; Labed, A.; Achouri, E. 2008. Etude de l'influence des rugosités artificielles sur les performances thermiques des capteurs solaires plans à air, Revue des Energies renouvelables 11(2) : 219-227.

7. Aoues, K.; Moummi, N.; Zellouf, M.; Moummi, A.; Labed, A.; Benchabane, A. 2009. Amélioration des performances thermiques d'un capteur solaire plan à air: Etude expérimentale dans la région de Biskra, Revue des Energies Renouvelables 12(2): 237-248. https://www.researchgate.net/publication/255597195.

8. Aoues, K.; Moummi, N.; Zellouf, M.; Benchabane, A. 2011. Thermal performance improvement of solar air flat plate collector: a theoretical analysis and an experimental study in Biskra, Algeria, International Journal of Ambient Energy. 32(2): 95-102. http://dx.doi.org/10.1080/01430750.2011.584469.

9. Labed, A.; Moummi N.; Benchabane A.; Aoues K.; Moummi A.2012. Performance investigation of singleand double-pass solar air heaters through the use of various fin geometries. International Journal of Sustainable Energy. 31(6): 423-434.

http://dx.doi.org/10.1080/14786451.2011.590899.

10. Labed, A.; Moummi, N.; Benchabane, A. 2012. Experimental investigation of various designs of solar flat plate collectors: application for the drying of green chili, Journal of Renewable and Sustainable Energy 4: 043116. http://dx.doi.org/10.1063/1.4742337.

11. Abene, A.; Dubois, V.; Le Ray, M.; Ouagued, A. 2004. Study of a solar air flat plate collector: use of obstacles and application for the drying of grape, International Journal of Food Engineering 65: 15-22. http://dx.doi.org/10.1016/j.jfoodeng.2003.11.002.

12. Ahmed-Zaid, A.; Messaoudi, H.; Abenne, A.; Le Ray, M.; Desmons, J.; Abed, B.1999. Experimental study of thermal performance improvement of a solar air flat plate collector through the use of obstacles: application for the drying of 'Yellow Onion', International Journal of Energy Research 23: 1083-1099. http://dx.doi.org/10.1002/(SICI)109914X(19991010)23:12<1083:AID-ER498>3.0.CO;2-Y.

13. Karsli, S. 2007. Performance analysis of new-design solar air collectors for drying applications, Renewable Energy 32: 1645-1660. http://dx.doi.org/10.1016/j.renene.2006.08.005.

14. Duffie, J.; Beckman, W. 1991. Solar Engineering of Thermal Processes, 2nd edition, Wiley-inter-science publication.

15. Parker, B.F.; Lindley, M.R.; Colliver, D.G.; Murphy, W.1993. Thermal performance of three solar air heaters, Solar Energy 51: 467-479. http://dx.doi.org/10.1016/0038-092X(93)90132-8.

16. Sodha, M.S.; Chandra, R. 1994. Solar drying systems and their testing procedure. A-review, Energy Convers Management 35: 219-267. http://dx.doi.org/10.1016/0196-8904(94)90004-3.

17. ASHRAE STANDARD 1991. Methods of testing to determine the thermal performance of solar collectors.
In Atlanta EU.

18. Ozgen, F.; Esen, M.; Esen, H. 2009. Experimental investigation of thermal performance of a double-flow solar air heater having aluminium cans, Renewable Energy 34: 2391-2398.

https://www.researchgate.net/.../223495833.

http://dx.doi.org/10.1016/j.renene.2009.03.029.

19. Akpinar, E.K.; Koçyigit, F. 2010. Experimental investigation of thermal performance of solar air heater having different obstacles on absorber plates, International Communications in Heat and Mass Transfer 37: 416-421.

https://www.researchgate.net/.../245055773. http://dx.doi.org/10.1016/j.icheatmasstransfer.2009.11. 007.

20. Konde, G. 1983. Resolution of de Luikov's Equations Applied in the Onion Drying with a view to Realize a Solar Blow-Dryers in Saheliens Countries, Ph.D. Thesis, Perpignan.

Kamel Aoues, Adnane Labed, Miloud Zellouf, Noureddine Moummi

\section{EXPERIMENTAL STUDY OF DRYING OF GREEN CHILI BY SOLAR AIR FLAT PLATE COLLECTOR USED OBSTACLES}

S u m m a r y

This paper presents the exploitation of the thermal solar energy converter by SAH in drying application. At once, we present the results of an experimental investigation performance for five configurations of air flat plate solar collector at Biskra (latitude $34^{\circ} 48^{\prime} \mathrm{N}$ and longitude $\left.5^{\circ} 44^{\prime} \mathrm{E}\right)$, Algeria. The thermal efficiency between absorber plate and air in flat-plate solar collector has been enhanced by introducing obstacles rows in the dynamic air vein of the collector. A flat plate solar collector, of $1.73 \mathrm{~m}^{2}$ area and $2.5 \mathrm{~cm}$ air gap, has been designed and constructed. These obstacles formed with two parts; the first part is perpendicular to fluid flow and the second part is inclined, they are mounted in a staggered pattern, are oriented perpendicular to the fluid flow and are soldered to the back plate. Experiments had been performed for air mass flow rates of $0.018 \mathrm{~kg} / \mathrm{s}$ and $0.043 \mathrm{~kg} / \mathrm{s}$. First case solar air heater without obstacle (case 1) and Four cases of SAH with obstacles (case 2, case 3, case 4 and case 5) were tested and compared. The highest efficiency had been obtained in case 5 at $0.043 \mathrm{~kg} / \mathrm{s}$. Also, the comparison between the thermal efficiency of the SAH tested in this study with the ones reported in the literature had been presented, and a good agreement had been found. In second parts of this travel, the results of the drying chili were presented. The solar collector Case 5 leads to a very significant improvement in the efficiency/temperature rise couple, and in the reduction in drying time of the product.

Keywords: Solar air heaters, solar drying, a new obstacle, thermal efficiency, moisture content, drying rate. 